\title{
Infestation index of Drosophila suzukii (Diptera: Drosophilidae) in small fruit in southern Brazil
}

\author{
Índice de infestação de Drosophila suzukii (Diptera: \\ Drosophilidae) em pequenas frutas no sul do Brasil
}

\author{
Jutiane Wollmann ${ }^{1 *}$ (D) (orcid.org/0000-0002-6301-2004) \\ Daniele Cristine Hoffmann Schlesener ${ }^{1}$ (1) (orcid.org/0000-0002-0653-5810) \\ Sávio Ritta Mendes' ${ }^{1}$ (1) (orcid.org/0000-0003-0775-9338) \\ Alexandra Peter Krüger ${ }^{1}$ (i) (orcid.org/0000-0002-1358-192X) \\ Liliane Nachtigall Martins ${ }^{1}$ (1) (orcid.org/0000-0003-4923-154X) \\ Daniel Bernardi2 (1) (orcid.org/0000-0003-4495-2575) \\ Mauro Silveira Garcia' (1) (orcid.org/0000-0002-5516-6935) \\ Flávio Roberto Mello Garcia' (1) (orcid.org/0000-0003-0493-1788)
}

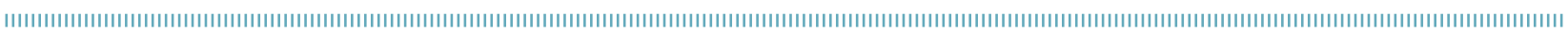

\begin{abstract}
The spotted-wing drosophila, Drosophila suzukii Matsumura, is considered the main insect pest of small fruit in the world. Identifying susceptible hosts is essential to develop management strategies. The aim of this study was to verify the level of $D$. suzukii infestation in blackberry, blueberry, strawberry, cattley guava and Surinam cherry fruits cultivated in the southern region in Brazil, and to determine the infestation index (II) per fruit. The studies were carried out during two harvests (2015/16 and 2016/17) in three areas with organic cultivation of small fruit. The highest level of $D$. suzukii natural infestation was observed in blackberry (40 to $65 \%$ infestation), and strawberry (approximately 30\% infestation) fruits. In contrast, blueberries were less preferred (< $7 \%$ infestation). For native fruit of the region (cattley guava and Surinam cherry), it was also verified infestation of the fly, demonstrating they are hosts for multiplication in the off-season periods of the other crops. In relation to II, blackberry and Surinam cherry provided a higher average number of insects per gram of fruit $(\approx 1.6$ adults of $D$. suzukii). In contrast, blueberries and cattley guava had the lowest insect ratio per gram of fruit ( $\approx 0.7$ adults per gram). The period between late spring to mid-autumn was considered ideal for the pest occurrence in the field. The knowledge of natural infestation levels is essential for understanding the behavior of the pest in the field, which will assist in the design of management strategies.
\end{abstract}

KEYWORDS: introduced species; spotted-wing drosophila; sampling studies; fruit host.
RESUMO: A drosófila-da-asa-manchada, Drosophila suzukii Matsumura, é considerada o principal inseto-praga de pequenos frutos no mundo. A identificação de hospedeiros suscetíveis é essencial para o desenvolvimento de estratégias de manejo. O objetivo deste estudo foi verificar o nível de infestação de $D$. suzukii em frutos de amoreira-preta, mirtileiro, morangueiro, araçazeiro e pitangueira cultivados na região no sul do Brasil e determinar os índices de infestação (II) por fruto. Os estudos foram realizados durante duas safras (2015/16 e 2016/17) em três áreas com cultivo orgânico de pequenas frutas. O maior nível de infestação natural de $D$. suzukii foi observado em amora-preta ( 40 a $65 \%$ de infestação) e morango (aproximadamente 30\% de infestação). Em contraste, o mirtilo foi menos preferido (<7\% de infestação). Para as frutas nativas da região (araçá e pitanga), também ocorreu infestação da mosca, demonstrando serem hospedeiros potenciais para a multiplicação da praga nos períodos de entressafras. Em relação ao II, amoras e pitangas proporcionaram um maior número médio de insetos por grama de fruto $(\approx 1,6$ adultos de $D$. suzukii). Por outro lado, mirtilos e araçás apresentaram a menor relação de insetos emergidos por gramas de frutos $(\approx 0,7$ adultos por grama). O período entre final da primavera até meados do outono foi considerado ideal para a ocorrência da praga no campo. O conhecimento dos níveis de infestação natural é fundamental para o entendimento do comportamento da praga no campo, o que auxiliará no delineamento de estratégias de manejo.

PALAVRAS-CHAVE: espécies introduzidas; drosófila-da-asa-manchada; amostragem; fruto hospedeiro. 


\section{INTRODUCTION}

Invasive species may pose a threat to natural ecosystems and exploit available resources differently or more efficiently than native species (DIEPENBROCK et al., 2016; HAMBY et al., 2016). Spotted-winged drosophila (SWD), Drosophila suzukii Matsumura (Diptera: Drosophilidae) is an invasive species originating in southeast Asia and is currently considered as one of the most important pests of small fruit, and stone fruit in different countries in North America, South America, Asia and Europe (WALSH et al., 2011; DEPRÁ et al., 2014; SCHLESENER et al., 2015; ANDREAZZA et al., 2017), with the ability to establish in Africa and Oceania (DOS SANTOS et al., 2017).

Since records outside his continent of origin (Asia), D. suzukii has become the target of numerous studies that seek to mitigate the economic impacts on different crops (BOLDA et al., 2010; WALSH et al., 2011). In the United States, annual losses can reach 500 million dollars, assuming damage levels of $30 \%$ (GOODHUE et al., 2011). Post-harvest losses due to the secondary selection of fruits in the storage facilities are added to the losses in the field, as well as losses due to the reduction in fruit shelf or storage life after infestation (LEE et al., 2011a).

The exception of most species of Drosophilidae, infesting damaged or decaying fruits, the females of the SWD have a serrated and sclerotized ovipositor system (BOLDA et al., 2010) with the ability to oviposit in healthy, ripe fruits or in an advanced ripening process (WALSH et al., 2011). Drosophila suzukii is highly polyphagous, and its preferred hosts are fine tegument fruits, such as strawberry (Fragaria $\times$ ananassa) (Rosaceae), blackberry (Rubus spp.) (Rosaceae), blueberry (Vaccinium spp.) (Ericaceae) and raspberry (Rubus spp.) (Rosaceae) (BOLDA et al., 2010; LEE et al., 2011b; ANDREAZZA et al., 2017), as well as a variety of uncultivated plants, such as Psidium guajava L. (Myrtaceae), Acca sellowiana (O.Berg) Burret (Myrtaceae), Solanum nigrum L. (Solanaceae), Eugenia uniflora L. (Myrtaceae), Sambucus nigra L. (Adoxaceae) and Eriobotrya japonica (Thumb.) Lindley (Rosaceae) (LEE et al., 2015; ANDREAZZA et al., 2017).

In Brazil, the largest small-fruit-producing are located in the south and southeast regions, highlighting Minas Gerais, São Paulo, Paraná and Rio Grande do Sul States, the last being considered the second largest small-fruit-producer in the country, mainly for strawberry crop, which has the largest production and planted area (FACHINELLO et al., 2011). The occurrence of $D$. suzukii has already been recorded in all locations cited previously (DEPRÁ et al., 2014; VILELA; MORI, 2014; GEISLER et al., 2015; ANDREAZZA et al., 2016; ZANUNCIO-JUNIOR et al., 2018). Furthermore, due to the fast dispersion capacity and multiplication hosts, it was verified that several regions of Brazil, as in the South of the country, are subject to increase the infestation of the pest in the coming years (ANDREAZZA et al., 2017; DOS SANTOS et al., 2017).

Because it is a new pest for Brazil, there is little information on the population behavior of the fly in the field during the harvest period or off-season of the preferential crops. Thus, determining the time of occurrence, the level and the rate of infestation of D. suzukii in the field is of great importance to determine the population level, as well as allowing to establish the status of the host plant as to susceptibility to infestation in a specific edaphoclimatic condition (KENIS et al., 2016). For these reasons, considering the damage caused by this insect and the large number of hosts we can find in the field (ANDREAZZA et al., 2017), it is necessary to research the pest infestation index in the production sites in order to outline the best management strategies (HAMBY et al., 2016). Thus, the objective of the study was to evaluate the level and the rates of natural infestation of $D$. suzukii in the field in different agricultural crops.

\section{MATERIAL AND METHODS}

For determining levels of D. suzukii infestation in the field, fruits were collected from five vegetable species of small fruit (blackberry, cattley guava, Surinam cherry, blueberry and strawberry) according to the availability and phenology of the crops (fruiting) (Table 1). The study was carried out for two consecutive years in the 2015/2016 (harvest 1) and 2016/2017 (harvest 2) agricultural seasons. For this purpose, three locations were used in the cities of Pelotas and Morro Redondo, Rio Grande do Sul, Brazil: Farm 1: Cascatinha (C)

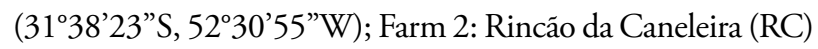

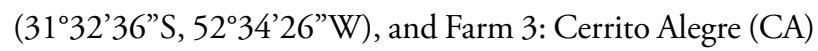
$\left(31^{\circ} 35^{\prime} 12^{\prime \prime} \mathrm{S}, 52^{\circ} 25^{\prime} 15^{\prime \prime} \mathrm{W}\right)$; these areas are at a distance of 30 to $60 \mathrm{~km}$ from each one. The adjacent landscape in the three localities is formed by remnants of semi-deciduous seasonal forest, interspersed with fields and shrub forests, where, in addition to arboreal species, other fruit species occur spontaneously such as loquat (E. japonica), guava (P. guajava) and Surinam cherry (E. uniflora).

In the Farm 1 (C), blackberries (Rubus spp.) cv. Brasos, yellow and red cattley guava (Psidium cattleianum) (Myrtaceae), and Surinam cherry (E. uniflora) were collected. The shortest distance between the orchards was approximately $3 \mathrm{~m}$ between blackberry and cattley guava, and the longest distance was about $50 \mathrm{~m}$ between the cattley guava and Surinam cherry crops. In the Farm 2 (RC), blackberries cv. Tupi, and blueberries (Vaccinium myrttillus L.) cv. Bluegem, Climax, and Powderblue were collected, that were approximately $100 \mathrm{~m}$ apart; and in the Farm 3 (CA), they were collected: strawberries (Fragaria $x$ ananassa) cv. Albion, Monterey, San Andreas, Benicia, Camarosa, and Camino Real grown in a semi-hydroponic 
system. For all farms, the cultivation system was based on organic fruit production throughout the crop cycle.

In each farm and plant species cultivated, about 30 fruits were collected weekly, randomly, which were taken directly from the plant from the beginning, until the complete maturation stage of each fruit species (Table 1). The fruits were collected and placed in thermal boxes $\left(25^{\circ} \mathrm{C}\right)$. In the laboratory, the fruits were weighed with the aid of a precision scale and placed in transparent plastic pots $(200 \mathrm{~mL})$ containing a thin layer of vermiculite $(1 \mathrm{~cm})$ and closed at the top with the respective plastic lids. For favoring the gas exchange between the internal and the external environment of the container, a hole $(2 \mathrm{~cm}$ in diameter) was opened in the upper part of the lids and covered with voile-type fabric to prevent the escape of insects during the emergence. Subsequently, the materials were placed in an air-conditioned room [temperature $24 \pm 2^{\circ} \mathrm{C}, 70 \pm 10 \%$ relative humidity $(\mathrm{RH}), 12 \mathrm{~h}$ photophase] until the emergence of insects. After emergence, the insects were removed and stored in "eppendorf" tubes (1.5 mL) filled with 70\% alcohol.

\section{STATISTICAL ANALYSES}

The parameters evaluated in each farm were: level of infestation, demonstrated by the percentage of infested fruits in the two years of collection and II per fruit. The II was determined by the average number of $D$. suzukii adults emerged per fruit, with the emergence ratio of $D$. suzukii being observed by the fruit weight, following the model proposed by KENIS et al. (2016). For counting and identification of D. suzukii, it was used a stereoscopic microscope (40x), through species-specific taxonomic observations (VLACH, 2013). For verifying the level of D. suzukii infestation in the plant species studied within each agricultural crop, the infestation percentage data were submitted to the $t$-test at $5 \%$ significance using the statistical software "R" version 2.15.1 (R DEVELOPMENT CORE TEAM, 2012).

\section{RESULTS}

\section{Infestation level of $D$. suzukii in small fruit in the field}

The level of $D$. suzukii infestation varied according to the fruit species evaluated and the local climatic conditions. However, in all fruit species collected in the different farms (blackberry, cattley guava, Surinam cherry, blueberry and strawberry), there was an emergence of $D$. suzukii adults in the laboratory indicating infestation in the field by females of the insect. The highest percentage of D. suzukii infestation in fruits occurred during the period between late spring and mid-autumn (Figs. 1 and 2). This fact is characterized by thermal ranges ranging from 18 to $25^{\circ} \mathrm{C}$ and relative humidity of approximately $80 \%$ (Fig. 1 ).

When comparing the percentage of $D$. suzukii infestation in the fruits, a greater infestation in blackberry $(F=10.11$; $t \geq 0.05)$, Surinam cherry $(F=22 ; t \geq 0.05)$, and strawberry $(F=17.08 ; t \geq 0.05)$ in the harvest $2016 / 2017$ (Fig. 2) was observed. However, for cattley guava and blueberry the percentage of infestation was similar in the 2015/2016 and 2016/2017 crop (Fig. 2).

The highest percentage (greater than $40 \%$ ) of oviposition was recorded in blackberry orchards in the RC and C farms, in both harvests, reaching 65\% infestation in the second year of sampling in the $\mathrm{C}$ farm (Fig. 2). Likewise, there was a high level of $D$. suzukii infestation in cattley guava (approximately $30 \%$ ) in harvest 1 and harvest 2, followed by Surinam cherry and strawberries (Fig. 2). The lowest level of infestation was

Table 1. Fruiting period of plant species used to determine the infestation rate of Drosophila suzukii in the field during the $2015 / 2016$ and $2016 / 2017$ harvests.

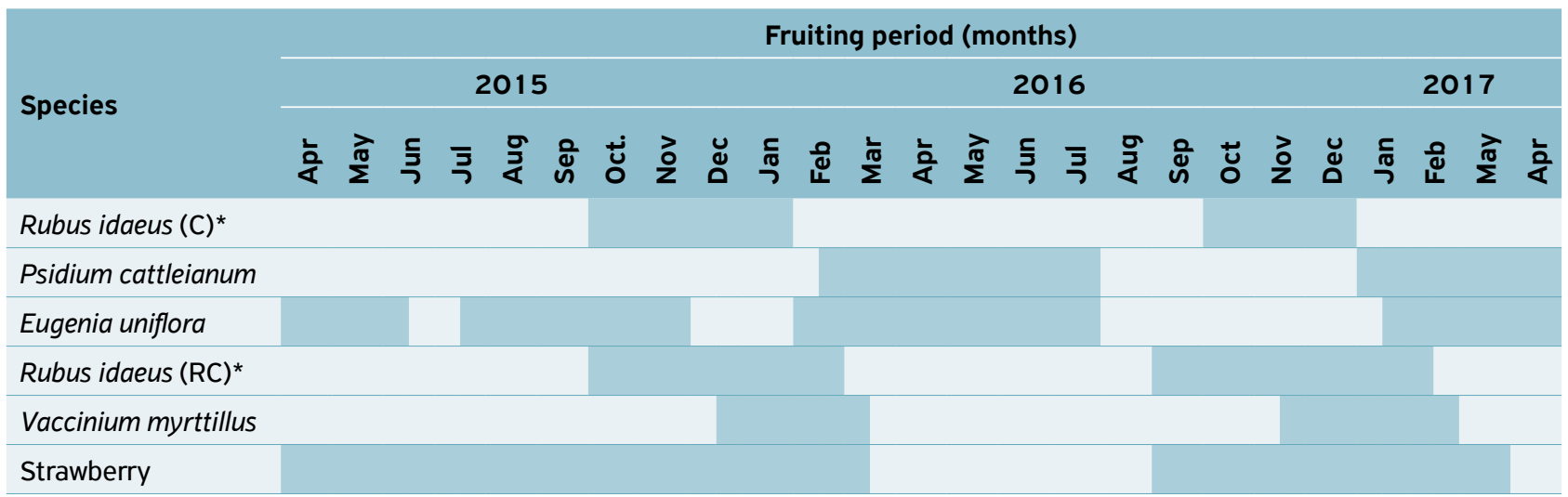

Colored cells represent the season with the occurrence of ripe and/or ripening fruits.

*Locations of Cascatinha (C) and Rincão da Caneleira (RC), respectively. 


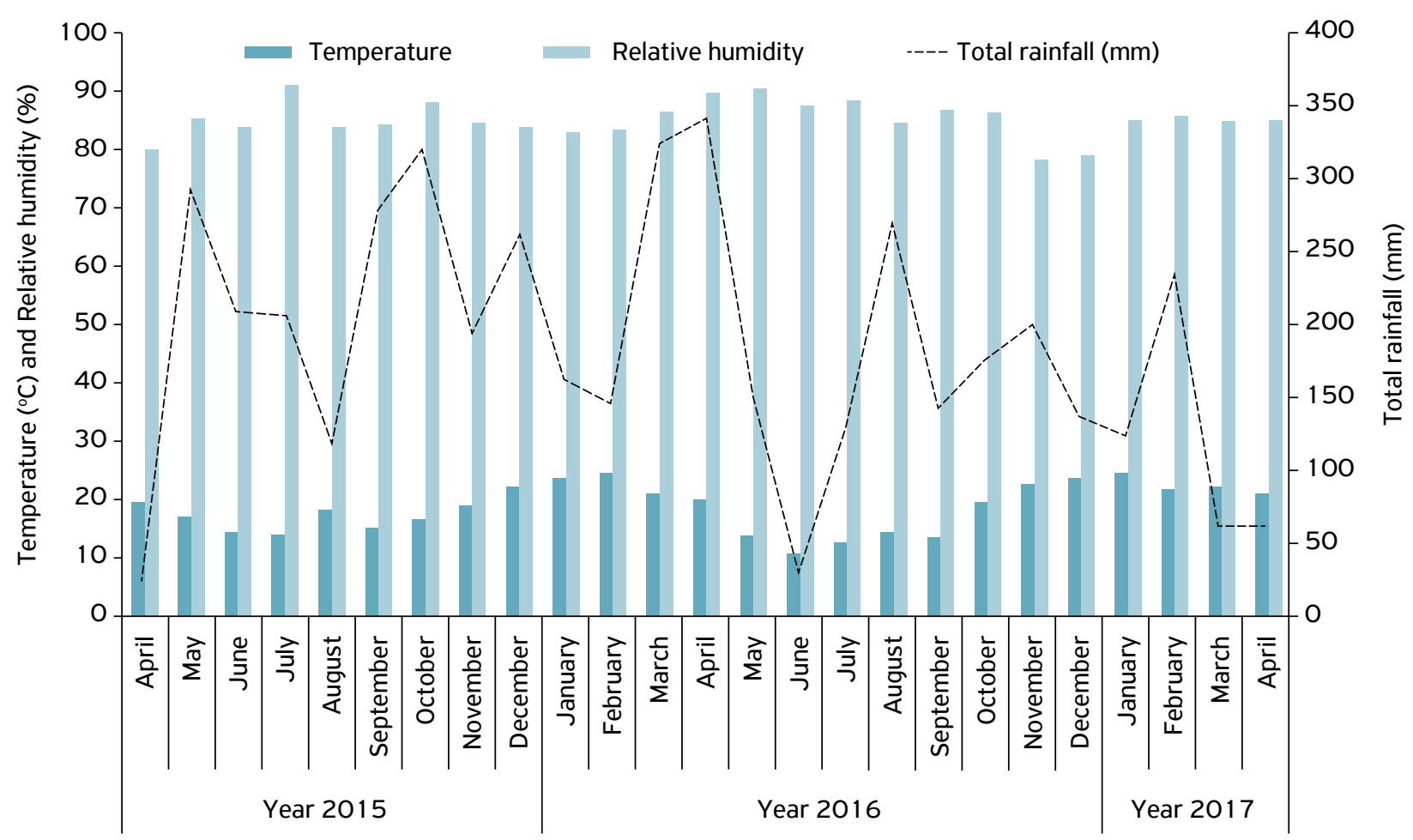

Figure 1. Monthly values of the meteorological parameters of temperature $\left({ }^{\circ} \mathrm{C}\right)$, relative humidity $(\%)$ and total precipitation $(\mathrm{mm})$ during the years 2015-2017.

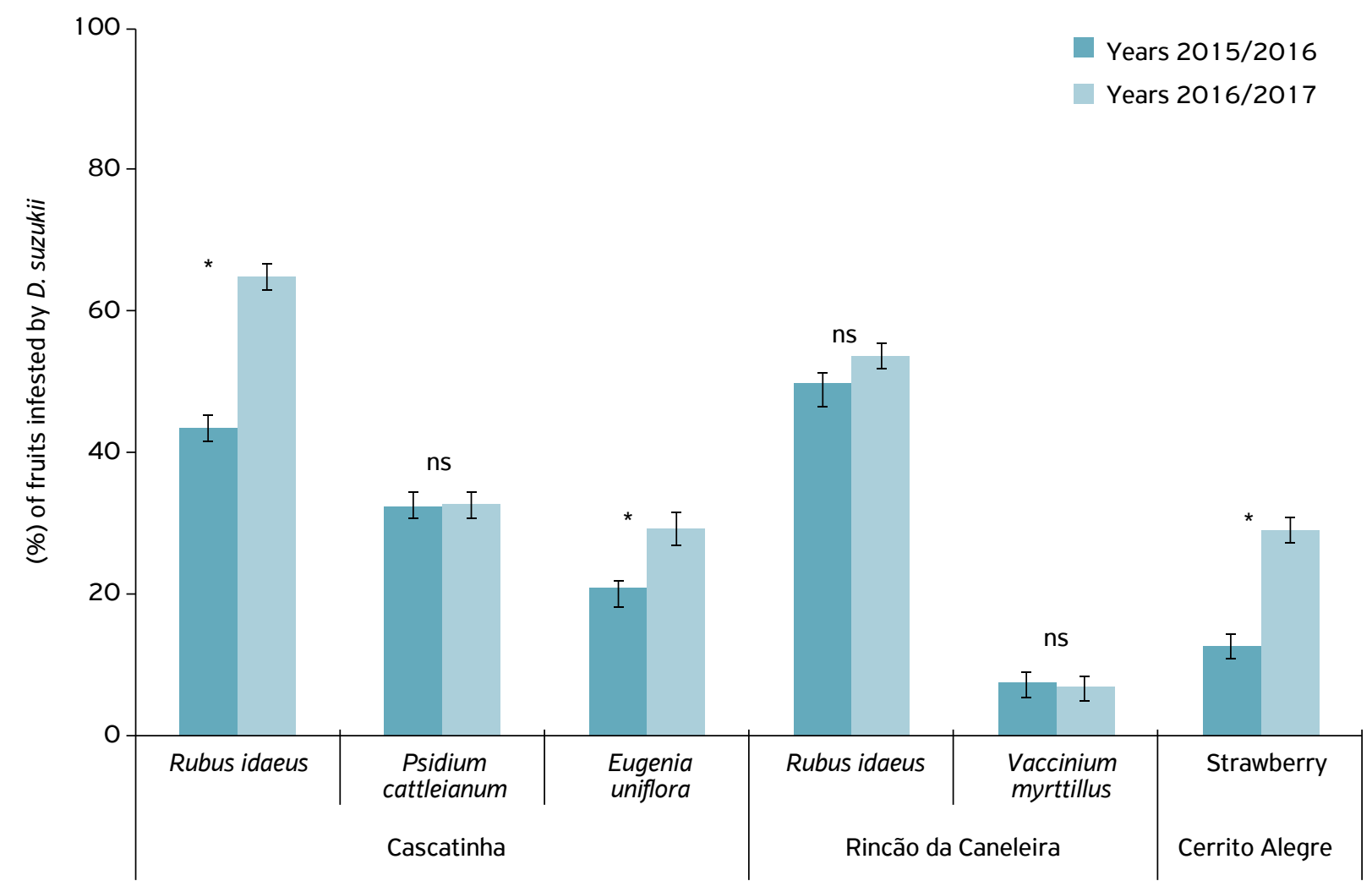

ns: not significant by Student $t$-test.

Figure 2. Percentage (\%) of fruits infested by Drosophila suzukii in the $2015 / 2016$ and $2016 / 2017$ agricultural seasons. 
observed in blueberries (Fig. 2). With the exception of the blueberry crop (RC farm), all other crops were found to increase in the percentage of infested fruits during harvest 2 (Fig. 2).

When comparing the infestation (\%) in the field, it was found that, when the overlapping of ripe fruits (blackberry, cattley guava, and Surinam cherry) occurred on farm 1 (C) (Table 1), D. suzukii adults had a higher level of infestation in blackberry in the two agricultural seasons evaluated when compared to cattley guava and Surinam cherry (Fig. 2). Likewise, in Farm 2 (RC), there was a greater search (\% of infestation) for blackberry (approximately 50\% of infested fruits) when compared to blueberry (approximately 7\% of infestation) (Fig. 1) in overlapping of crops with ripe fruits (Table 1).

\section{D. suzukii infestation index by fruit}

During the two years of sampling, it was verified that blackberries had the highest II (number of adults emerged per fruit) (Fig. 3), ranging from 11 (harvest 1) to 6 (harvest 2) (RC farm) and 8 (harvest 1) to 9 (harvest 2) (farm C) (Fig. 3). However, the smallest amount of $D$. suzukii adults emerged per fruit was observed in blueberries for harvests 1 and $2(<2$ adults of the fly per fruit) (Fig. 3). When verifying the relationship between fruit weight $(\mathrm{g})$ and the number of insects emerged from D. suzukii per fruit, blackberries and Surinam cherry showed a higher average number of insects per gram of fruit (approximately 1.6 D. suzukii adults per gram of fruit) in the two evaluated agricultural seasons (Fig. 4). In contrast, blueberries and cattley guava had the lowest relationship between insects emerged per gram of fruit (approximately 0.7 adults per gram) in the harvest 1 (Fig. 4). However, in the harvest 2, the lowest index of adults emerged in relation to fruit weight was observed in strawberry (0.63 adults per gram of fruit) (Fig. 4).

\section{DISCUSSION}

In this study, it was found that exotic species (blackberry, blueberry and strawberry) and native species (Surinam cherry and cattley guava) were susceptible to $D$. suzukii infestation in the field. However, during the two consecutive years of

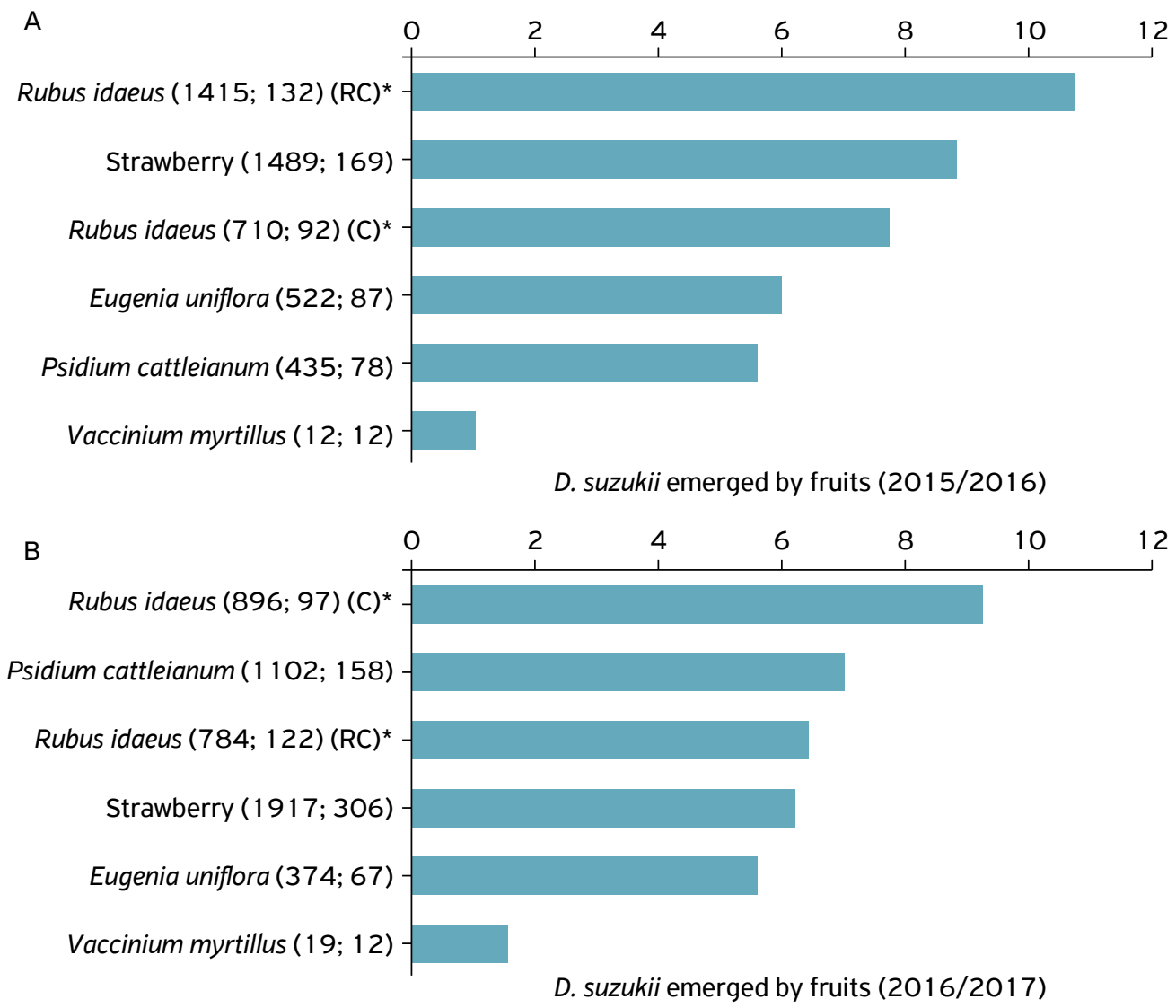

*Localities of Rincão da Caneleira (RC) and Cascatinha (C).

Figure 3. Total number of Drosophila suzukii adults emerged per fruit in the $2015 / 2016$ (A) and 2016/2017 (B) harvest. Numbers in parentheses following the fruits names indicate the total of Drosophila suzukii adults emerging from the respective fruit and the total of infested fruits, respectively. 
evaluations, there was a high level of D. suzukii infestation in blackberries. On the other hand, blueberries were less susceptible compared to other fruits. The results found in the present study meet those observed in laboratory studies, whereby $D$. suzukii females had a higher rate of oviposition (eggs by fruit) and a greater viability of the biological cycle (egg to adult) in blackberries and raspberries when compared to strawberries, cherries, blueberries and grapes (LEE et al., 2011b; BELLAMY et al., 2013).

Although the volatile emission rate by fruits and leaves, degrees brix ${ }^{\circ}$ and $\mathrm{pH}$ of the collected fruits has not been evaluated, studies show that adults of the SWD are influenced by these factors for the search for hosts, which varies from species to species (LEE et al., 2011b; KEESEY et al., 2015; LITTLE et al., 2016). This behavior was verified when analyzing the farms that showed the occurrence of overlapping crops with fruits according to the phenology of the crop (fruiting period) (farm $\mathrm{C}$ and farm RC). The preference and level of blackberry infestation may be associated with the beginning of the fruiting period when compared to other crops. This vegetative behavior may have triggered a greater release of volatiles by the foliage, which may have been an initial stimulus and a signal for the SWD of the existence of nearby fruits (KEESEY et al., 2015).

Despite studies show that $D$. suzukii females have a preference for ripe fruits (LEE et al., 2011b; BERNARDI et al., 2016), because they provide a greater nutritional balance of carbohydrate and protein for the larval phase (JARAMILLO et al., 2015; PHAM; RAY, 2015), it was verified that D. suzukii emerged in the laboratory from semi-ripe fruits of Surinam cherry (orange color) and blackberry (rose colored) collected in the field. However, few insects have emerged from semi-ripe strawberry fruits, as seen in previous studies (BERNARDI et al., 2016).

Another positive contributing factor to the highest rates of insect infestation in the field was the environmental conditions of the region. In view of this, it was observed that the highest rates of $D$. suzukii infestation in the evaluated plant species were related from late spring to mid-autumn, a period associated with fruiting. The pattern of occurrence and population increases of $D$. suzukii infestation verified during two years of evaluations are similar to that observed for populations of D. suzukii that occur in small fruit producing regions

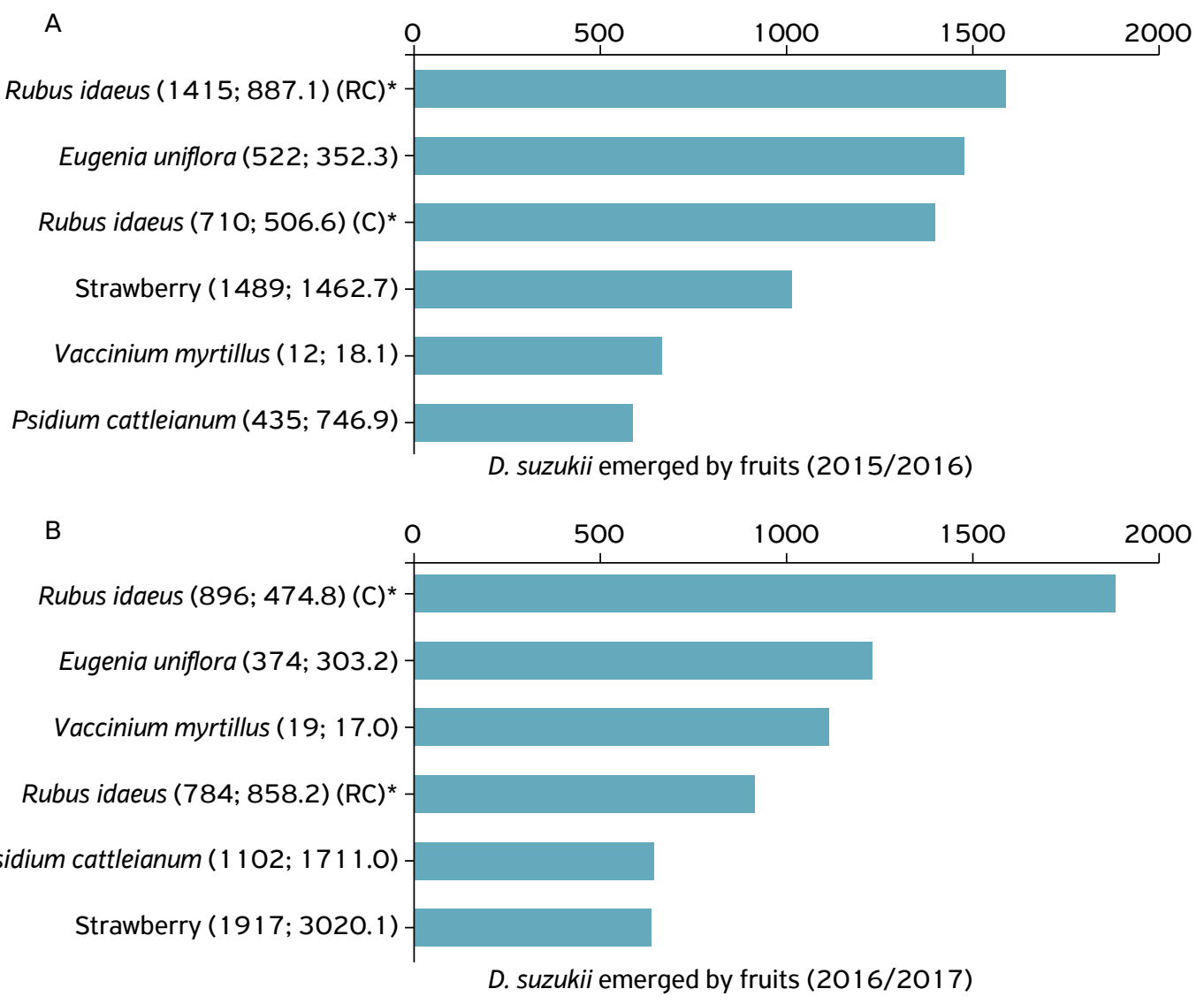

*Localities of Rincão da Caneleira (RC) and Cascatinha (C).

Figure 4. Total number of Drosophila suzukii emerged by weight of fruit collected in the 2015/2016 (A) and 2016/2017 (B) harvests. Number in parentheses following the fruit name indicate the total of Drosophila suzukii adults emerged from the respective fruit and the total weight of infested fruits, respectively. 
of the United States (autumn and spring period) (LEE et al., 2011b). The highest occurrences of D. suzukii during spring are associated with the prevalence of favorable temperatures for species (temperature between 18 to $25^{\circ} \mathrm{C}$ ), considered the ideal temperature for the biological development of D. suzukii (RYAN et al., 2016). In addition, the increase in relative air humidity during autumn provided a greater reproductive potential and survival of the pest (TOCHEN et al., 2015), and, consequently, population increases in this period. This behavior occurred due to high air humidity (above 70\%) and temperature $\left(18\right.$ to $\left.25^{\circ} \mathrm{C}\right)$, they are environmental factors considered essential for the biological development of the species (TOCHEN et al., 2015).

During the winter, in which there was a thermal variation of 8 to $14^{\circ} \mathrm{C}$, low rates of infestation of $D$. suzukii were recorded in all fruit species evaluated in the field. Although the rate of infestation was observed to a lesser extent, the occurrence of the species in the field demonstrates the pest's ability to remain active in the environment during the cold periods of the regions. Another factor that may have contributed to maintaining D. suzukii in the field in southern Brazil during low temperatures is the predominance of alternative hosts such as loquats, E. japonica, at the orchard border or inside the native forest (GEISLER et al., 2015; ANDREAZZA et al., 2017). This vegetable species has a fruiting capacity during the winter in Brazil and may have served as a "refuge" and food for the D. suzukii survival during the critical periods (June and July), until the re-establishment of the main culture in the field (LEE et al., 2015).

In view of the climatic characteristics of the region that favor the activity of D. suzukii in agroecosystems practically the whole year, predisposing to greater risks of damage, the information provided by this study may serve as a basis for new research to outline strategies for sustainable management of the pest. In this sense, the suppression of $D$. suzukii may include management tactics, such as mass capture with monitoring traps (BELLAMY et al., 2013), pest management in alternative hosts, and orchard cleaning to avoid initial insect outbreaks (LEE et al., 2015; ZANUNCIO-JUNIOR et al., 2018). It also can be useful programing to reduce the interval between the harvest of the fruits, allowing the removal or elimination of the ripe fruits (more susceptible to the pest attack) or spoiled of the cultivated area (WALSH et al., 2011). Other strategy is assist producers in making management decisions before the fruit has fully ripened, as it is more susceptible to pest infestation.

ACKNOWLEDGEMENTS: The authors would like to thank Coordenação de Aperfeiçoamento de Pessoal de Nível Superior (CAPES) - Finance Code (OO1) for the granting scholarships for Wollmann, J.; Schlesener, D.C.H.; Krüger, A.P.; e Martins, L.N.

FUNDING: This study was financed in part by the Coordenação de Aperfeiçoamento de Pessoal de Nível Superior - Brasil (CAPES) - Finance Code 001.

CONFLICT OF INTEREST: All authors declare that they have no conflict of interest.

ETHICAL APPROVAL: Not applicable.

AVAILABILITY OF DATA AND MATERIAL: The datasets generated and/or analyzed during the current study are available from the corresponding author on reasonable request.

AUTHORS' CONTRIBUTIONS: Conceptualization and Methodology: Wollmann, J.; Garcia, M.S.; Garcia, F.R.M. Investigation: Wollmann, J.; Schlesener, D.C.H.; Mendes, S.R.; Krüger, A.P.; Martins, L.N. Formal analysis: Wollmann, J.; Bernardi, D.; Garcia, F.R.M. Writing - original draft: Wollmann, J.

ANDREAZZA, F.; HADDI, K.; OLIVEIRA, E.E.; FERREIRA, J.A.M. Drosophila suzukii (Diptera: Drosophilidae) arrives at Minas Gerais state, a main strawberry production region in Brazil. Florida Entomologist, v.99, n.4, p.796-798, 2016. https://doi. org/10.1653/024.099.0439
ANDREAZZA, F.; BERNARDI, D.; DOS SANTOS, R.S.S.; GARCIA, F.R.M.; OLIVEIRA, E.E.; BOTTON, M.; NAVA, D.E. Drosophila suzukii in Southern Neotropical region: Current status and futures perspectives. Neotropical EntomologY, v.46, n.6, p.591-60, 2017. https://doi.org/10.1007/s13744-017-0554-7 
BELLAMY, D.E.; SISTERSON, M.S.; WALSE, S.S. Quantifying host potentials: indexing post-harvest fruits for spotted wing drosophila, Drosophila suzukii. PLoS ONE, v.8, n.4, p.e61227, 2013. https:// doi.org/10.1371/journal.pone.0061227

BERNARDI, D.; ANDREAZZA, F.; BOTTON, M.; BARONIO, C.A.; NAVA. D.E. Susceptibility and interactions of Drosophila suzukii and Zaprionus indianus (Diptera: Drosophilidae) in damaging strawberry. Neotropical Entomology, v.46, n.1, p.1-7, 2017. https://doi.org/10.1007/s13744-016-0423-9

BOLDA, M.P.; GOODHUE, R.E.; ZALOM, F.G. Spotted wing drosophila: potential economic impact of a newly established pest. Giannini Foundation of Agricultural Economics, v.13, n.3, p.5-8, 2010.

DEPRÁ, M.; POPPE, J.L.; SCHMITZ, H.J.; DE TONI, D.C.; VALENTE, V.L.S. The first records of the invasive pest Drosophila suzukii in South American continent. Journal of Pest Science, v.87, n.3, p.379383, 2014. https://doi.org/10.1007/s 10340-014-0591-5

DIEPENBROCK, L.M.; SWOBODA-BHATTARAI, K.A.; BURRACK, H.J. Ovipositional preference, fidelity, and fitness of Drosophila suzukii in a co-occurring crop and non-crop host system. Journal of Pest Science, v.89, n.3, p.761-769, 2016. https://doi.org/10.1007/ s10340-016-0764-5

DOS SANTOS, L.A.; MENDES, M.F.; KRÜGER, A.P.; BLAUTH, M.L.; GOTTSCHALK, M.S.; GARCIA, F.R.M. Global potential distribution of Drosophila suzukii (Diptera, Drosophilidae). PLoSONE, v.12, n.3, p.1-13, 2017. https://doi.org/10.1371/journal.pone.0174318

FACHINELLO, J.C.; PASA, M.S.; SCHMTIZ, J.D.; BETEMPS, D.L. Situação e perspectivas da fruticultura de clima temperado no Brasil. Revista Brasileira de Fruticultura, v.33, n.esp., p. 109-120, 201 1. https://doi.org/10.1590/SO100-29452011000500014

GEISLER, F.C.S.; SANTOS, J.; HOLDEFER, D.R.; GARCIA, F.R.M. Primeiro registro de Drosophila suzukii (Matsumura, 1931) (Diptera: Drosophilidae) para o estado do Paraná, Brasil e de novos hospedeiros. Revista de Ciências Ambientais, v.9, n.2, p.125-129, 2015. http://dx.doi.org/10.18316/1981-8858.15

GOODHUE, R.E.; BOLDA, M.; FARNSWORTH, D.; WILLIAMS, J.C.; ZALOM, F.G. Spotted wing drosophila infestation of California strawberries and raspberries: economic analysis of potential revenue losses and control costs. Pest Management Science, v.67, n. 11 , p.1396-1402, 2011 . https://doi.org/10.1002/ps.2259

HAMBY, K.A.; BELLAMY, D.E.; CHIU, J.C.; LEE, J.C.; WALTON, V.M.; WIMAN, N.G.; YORK, R.M.; BIONDI, A. Biotic and abiotic factors impacting development, behavior, phenology, and reproductive biology of Drosophila suzukii. Journal of Pest Science, v.89, n.3, p.605619, 2016. https://doi.org/10.1007/s10340-016-0756-5

JARAMILLO, S.L.; MEHLFERBER, E.; MOORE, P.J. Life-history trade-offs under different larval diets in Drosophila suzukii (Diptera: Drosophilidae). Physiological Entomology, v.40, n. 1, p.2-9, 2015. https://doi.org/10.1111/phen. 12082

KEESEY, I.W.; KNADEN, M.; HANSSON, B.S. Olfactory specialization in Drosophila suzukii supports an ecological shift in host preference from rotten to fresh fruit. Journal of Chemical Ecology, v.41, n.2, p.121-128, 2015. https://doi.org/10.1007/ s10886-015-0544-3
KENIS, M.; TONINA, L.; ESCHEN, R.; VAN DER SLUIS, B.; SANCASSANI, M.; MORI, N.; HAYE, T.; HELSEN, H. Non-crop plants used as hosts by Drosophila suzukii in Europe. Journal of Pest Science, v.89, n.3, p.735-748, 2016. https://doi.org/10.1007/ s10340-016-0755-6

LEE, J.C.; BRUCK, D.J.; DREVES, A.J.; IORIATTI, C.; VOGT, H.; BAUFELD, P. In Focus: spotted wing drosophila, Drosophila suzukii, across perspectives. Pest Management Science, v.67, n. 11 , p. 1349-1351, 2011 a. https://doi.org/10.1002/ps.2271

LEE, J.C.; BRUCK, D.J.; CURRY, H.; EDWARDS, D.; HAVILAND, D.R.; VAN STEENWYK, R.A.; YORGEY, B.M. The susceptibility of small fruits and cherries to the spotted-wing drosophila, Drosophila suzukii. Pest Management Science, v.67, n. 1 1, p.1358-1367, 201 1b. https://doi.org/10.1002/ps.2225

LEE, J.C.; DREVES, A.J.; CAVE, A.M.; KAWAI, S.; ISAACS, R.; MILLER, J.C.; VAN TIMMEREN, S.; BRUCK, D.J. Infestation of wild and ornamental noncrop fruits by Drosophila suzukii (Diptera: Drosophilidae). Annals of the Entomological Society of America, v.108, n.2, p.117-129, 2015. https://doi.org/10.1093/aesa/ sauO 14

LITTLE, C.M.; CHAPMAN, T.W.; MOREAU, D.L.; HILLIER, N.K. Susceptibility of selected boreal fruits and berries to the invasive pest Drosophila suzukii (Diptera: Drosophilidae). Pest Management Science, v.73, n.1, p.160-166, 2016. https://doi.org/10.1002/ ps. 4366

PHAM, C.K.; RAY, A. Conservation of olfactory avoidance in Drosophila Species and identification of repellents for Drosophila suzukii. Scientific Reports, v.5, p.1-8, 2015. https://doi. org/10.1038/srep 11527

R DEVELOPMENT CORE TEAM. R: A Language and Environment for Statistical Computing. Vienna: R Foundation for Statistical Computing, 2012. Available from: https://wwwr-projectorg/. Access on: Nov. 20, 2017.

RYAN, G.D.; MILJANOWICZ, L.; WILKINSON. F.; KORNYA, M.; NEWMAN, J.A. Thermal tolerances of the Spotted-wing Drosophila Drosophila suzukii (Diptera: Drosophilidae). Journal of Economic Entomology, v.109, n.2, p.746-752, 2016. https:// doi.org/10.1093/jee/tow006

SCHLESENER, D.C.H.; WOLLMANN, J.; NUNES, A.M.; CORDEIRO, J.; GOTTSCHALK, M.S.; GARCIA, F.R.M. Drosophila suzukii: nova praga para a fruticultura brasileira. O Biológico, v.77, n. 1, p.47-54, 2015.

TOCHEN, S.; WOLTZ, J.M.; DALTON, D.T.; LEE, J.C.; WIMAN, N.G.; WALTON, V.M. Humidity affects populations of Drosophila suzukii (Diptera: Drosophilidae) in blueberry. Journal of Applied Entomology, v.140, n.1-2, p.47-57, 2015. https://doi.org/10.1111/jen.12247

VILELA, C.R.; MORI, L. The invasive spotted-wing Drosophila (Diptera Drosophilidae) has been found in the city of São Paulo (Brazil). Revista Brasileira de Entomologia, v.58, n.4, p.371-375, 2014. http://dx.doi.org/10.1590/S0085-56262014000400004

VLACH, J. Identifying Drosophila suzukii. Salem: Oregon Department of Agriculture, 2013. Available from: http:// www.oregon.gov/oda/shared/documents/publications/ippm/ spottedwingdrosophilaidkey.pdf/. Access on: Nov. 152017. 
ZANUNCIO-JUNIOR, J.S.; FORNAZIER, M.J.; ANDREAZZA, F.; CULIK, M.P.; MENDONÇA, L.P.; OLIVEIRA, E.E.; MARTINS, D.S.; COSTA, H.; VENTURA, J.A. Spread of two invasive flies (Diptera: Drosophilidae) infesting commercial fruits in Southeastern Brazil. Florida Entomologist, v.101, n.3, p.522-525, 2018. https://doi. org/10.1653/024.101.0328
WALSH, D.B.; BOLDA, M.P.; GOODHUE, R.E.; DREVES, A.J.; LEE, J.; BRUCK, D.J.; WALTON, V.M.; O’NEAL, S.D.; ZALOM, F.G. Drosophila suzukii (Diptera: Drosophilidae): Invasive pest of ripening soft fruit expanding its geographic range and damage potential. Journal of Integrated Pest Management, v.2, n.1, p.1-8, 2011. https:// doi.org/10.1603/IPM 10010 